УДК 343.326:179.7

https://doi.org/10.24866/1813-3274/2021-1/134-152

Т. В. Квасникова ${ }^{1}$, Дальневосточный федеральный университет,

г. Владивосток, Россия

E-mail: kvasnikova.tv@dvfu.ru

Д. В. Лобач ${ }^{2}$, Дальневосточный федеральный университет, г. Владивосток, Россия

E-mail: lobach.dv@dvfu.ru

М. Сиссоко ${ }^{3}$, Дальневосточный федеральный университет, г. Владивосток, Россия

E-mail: sissoko.m@dvfu.ru

\title{
СУИЦИДАЛЬНЫЙ ТЕРРОРИЗМ КАК РАЗНОВИДНОСТЬ ТЕРРОРИСТИЧЕСКОЙ ДЕЯТЕЛЬНОСТИ
}

Аннотация. В статье рассматриваются криминологические особенности суицидального терроризма как вида политического насилия в наше время. Несмотря на то, что суицидальный терроризм проявляется в разные исторические эпохи, однако только со второй половины XX века терроризм смертников становится широко применяемой тактикой насильственного политического давления. Проведённый анализ обзорных позиций по данной теме позволяет определить суицидальный терроризм как насильственную практику, направленную на причинение максимального ущерба гражданскому населению и (или) гражданским объектам, а равно государственным органам власти, учреждениям или международным организациям в целях устрашения населения и воздействия на официальные органы власти, которая при этом сопровождается сознательным отказом исполнителя от спасения сво-

${ }^{1}$ Татьяна Владимировна Квасникова, кандидат юридических наук, доцент кафедры уголовного права и криминологии Юридической школы Дальневосточного федерального университета, г. Владивосток, Россия.

${ }^{2}$ Дмитрий Владимирович Лобач, кандидат юридических наук, доцент кафедры теории и истории государства и права Юридической школы Дальневосточного федерального университета, г. Владивосток, Россия.

${ }^{3}$ Муктар Сиссоко, аспирант кафедры уголовного права и криминологии Юридической школы Дальневосточного федерального университета, г. Владивосток, Россия.

Для цитирования: Квасникова Т. В., Лобач Д. В., Сиссоко М. Суицидальный терроризм как разновидность террористической деятельности // Азиатско-Тихоокеанский регион: экономика, политика, право. 2021. №. 1. С. 134-152. https://doi.org/10.24866/1813-3274/2021-1/134-152.

(C) Квасникова Т. В., Лобач Д. В., Сиссоко М., 2021 
ей жизни. При этом сам суицидальный терроризм представлен в двух формах: классический суицидальный терроризм и суицидальный терроризм высокой вероятности. На основании анализа статистических данных относительно распространения суицидального терроризма в мире определяется резкая тенденция роста данного вида терроризма в XXI веке, а также прослеживаются корреляционные изменения удельного коэффициента причинения вреда в зависимости от тактики суицидального терроризма. Рассматриваются два ключевых подхода касательно понимания причин суицидального терроризма. В контексте первого подхода суицидальный терроризм объясняется с позиции религиозного самосознания и кризиса культурно-национальных ценностей, исторически складывающихся в традиционном обществе. В рамках второго подхода детерминация суицидального терроризма обусловливается социальным протестом против несправедливой системы социальной организации и сложившихся общественных отношений. В рамках этого подхода общеопасные акты самоубийства совершаются в целях воздействия на публичные органы власти с тем, чтобы изменить социальную стратификацию, ликвидировать дискриминационные отношения, редуцировать риски социальной несправедливости, а также изменить сложившуюся систему распределения общественных благ.

Ключевые слова: терроризм, террористическая преступность, политическое насилие, суицидальный терроризм, терроризм смертников, криминальный суицид, религиозный терроризм, классический суицидальный терроризм и суицидальный терроризм высокой вероятности, расширение географии террористических угроз. 
Tatyana V. Kvasnikova ${ }^{1}$, Far Eastern Federal University, Vladivostok, Russia E-mail: kvasnikova.tv@dvfu.ru

Dmitry V. Lobach ${ }^{2}$, Far Eastern Federal University, Vladivostok, Russia E-mail: lobach.dv@dvfu.ru

Muktar Sissoko ${ }^{3}$, Far Eastern Federal University, Vladivostok, Russia

E-mail: sissoko.m@dvfu.ru

\section{SUICIDE TERRORISM AS A KIND OF TERRORISTIC ACTIONS}

Abstract. The article examines the criminological characteristics of suicide terrorism as a form of political violence in the contemporary world. Despite the fact that suicide terrorism has been seen in different historical epochs, only in the second half of the twentieth century terrorism of suicide bombers became a widespread violent practice. The analysis of survey items on this topic allows to define suicidal terrorism as violent practices aimed at causing the maximum damage to the civilian population and (or) civilian objects, as well as state authorities, institutions or international organizations in order to intimidate the population and influence the official authorities; these acts inovlve a conscious refusal of the contractosr from their own lives. Thus suicidal terrorism is presented in two forms: classic suicide terrorists and suicide terrorists of high probability. Analysis of statistical data on the spread of suicide terrorism in the world allowed determining a sharp growth trend of this type of terrorism in the twenty-first century, as well as the correlation of changes in specific factor of the injury depending on the tactics of suicide terrorism. Discusses two key approaches to understand of the causes of suicide terrorism. The first approach explains suicidal terrorism from a position of religious consciousness and the crisis of national and cultural values, which has been historically prevailing in a traditional society. In the second approach, the determination of suicide terrorism is determined by social protest against an unjust system of social organization and existing social relations. In this approach, dangerous acts of suicide are committed in order to influence public authorities, in order to change social stratification, to eliminate discrimina-

\footnotetext{
${ }^{1}$ Tatyana Vladimirovna Kvasnikova, Candidate of Legal Sciences, Associate Professor of the Department of Criminal Law and Criminology of the Law School, Far Eastern Federal University, Vladivostok, Russia.

${ }^{2}$ Dmitry Vladimirovich Lobach, PhD in Law, Associate Professor of the Department of Theory and History of State and Law of the Law School, Far Eastern Federal University, Vladivostok, Russia.

${ }_{3}$ Muktar Sissoko, PhD Student of the Department of Criminal Law and Criminology of the Law School, Far Eastern Federal University, Vladivostok, Russia.

For citing: Kvasnikova T. V., Lobach D. V., Sissoko M. Suicide terrorism as a kind of terroristic actions // PACIFIC RIM: Economics, Politics, Law. 2021. No. 1. P. 134-152. https://doi.org/10.24866/18133274/2021-1/134-152.
} 
tory attitudes, to reduce the risks of social injustice and to change the existing system of distribution of public goods.

Key words: terrorism; terrorist crime; political violence, suicidal terrorism, suicide terrorism, criminal suicide, religious terrorism, classic suicidal terrorism and suicidal terrorism of high probability, expansion of the geography of terrorist threats.

Глобализация международных отношений, выражающаяся во всемирной экономической, политической, социально-культурной и религиозной интеграции и унификации, сопровождается деструктивными явлениями, среди которых особое внимание обращает на себя такая форма политического насилия, как терроризм, который посягает на суверенитет, политическую независимость и территориальную целостность государств, а также дестабилизирует региональную безопасность и угрожает международному миру. Международная опасность современного терроризма выражается в трансформации, консолидации и функциональной кооперации национальных террористических структур, которые создают некое подобие международного криминального интернационального движения (сети террористических структур, взаимодействующих и аффилированных друг с другом), а также в расширении географии террористических угроз и их интенсификации на региональном уровне.

Терроризм в современном мире является одной из главных причин дестабилизации общества и дезорганизации государственной системы власти и управления, что закономерно порождает социальные конфликты, эскалацию насилия и нарушение гражданского мира. При этом терроризм, будучи сложным и многогранным явлением социальной действительности, исторически эволюционирует, что обусловливает создание новых видов террористической деятельности и экстенсивное их распространение. В этом плане обращает на себя внимание получивший широкое распространение в XXI веке терроризм, осуществляемый посредством использования террористов-смертников в качестве оружия.

В историческом контексте о суицидальном терроризме известно с давних времен. Так, в литературе отмечается, что ещё в I веке нашей эры в целях создания единого еврейского государства, независимого от Рима, в Иудее действовала террористическая организация сикариев, члены которой осуществляли террористические акты через нападения на представителей римских властей в Иерусалиме, при этом они шли на совершение актов политического насилия с осознанием своей скорой неминуемой смерти [1, p. 55-60]. В VII веке в исламе возникло самостоятельное движение, известное как Шиизм. Несмотря на то, что суицидальный терроризм в современном мире широко используется террористическими организациями суннитского толка, однако не надо забывать, что исторически именно представители шиизма взяли на вооружение эту практику для уничтожения политических и рели- 
гиозных противников [2, с. 127]. В XI веке в Иране существовала секта исмаилитов ассасинов (от арабского слова «хашшашин» - употребляющий гашиш), которые прибегали к использованию террористов-смертников для достижения политических целей. Секта ассасинов активно использовала наркотические средства в совокупности с психологическими техниками в целях изменения индивидуального сознания и последующего манипулирования человеком, превращая его, по сути, в адепта, готового выполнять любые команды руководства организации. В исторической ретроспективе можно найти и другие примеры суицидального терроризма, что доказывает объективную востребованность такой практики политического насилия в разные исторические эпохи. Вместе с тем только со второй половины XX века терроризм смертников становится широко применяемой насильственной практикой, осуществляемой в разных странах и на международном уровне, связанной с воздействием на органы государственной власти и международные организации, а также с запугиванием общества и подавлением институтов гражданского общества.

Изучение обзорных позиций относительно определения суицидального терроризма, высказанных в специальной отечественной и зарубежной литературе, позволяет дать следующее определение данному явлению. Суицидальный терроризм (терроризм с использованием смертников) представляет собой насильственную практику, направленную на причинение максимального ущерба гражданскому населению и (или) гражданским объектам, а равно государственным органам власти, учреждениям и международным организациям с целью устрашения и воздействия на официальные органы власти, сопровождающуюся сознательным отказом исполнителя от спасения своей жизни [3; 4; 5].

С определённой долей условности терроризм смертников можно определить как агрессивное самоубийство, сопровождаемое стремлением к максимальному причинению ущерба гражданскому населению, учреждениям и государственным структурам. Другими словами, суицид становится тактическим приёмом, который используется в преступных целях организаторами террористических актов. При этом в зависимости от вероятности наступления летального исхода сам по себе суицидальный терроризм можно рассматривать в двух формах: классический суицидальный терроризм и суицидальный терроризм высокой вероятности.

Классический суицидальный терроризм представляет собой такую форму террористического суицида, когда непосредственный исполнитель, осознавая характер совершаемых действий и последствия (самоубийство и причинение вреда третьим лицам), совершает террористический акт, который неминуемо приводит к летальному исходу самого исполнителя. Подобная форма суицидального терроризма связана с особой мотивацией и большими волевыми усилиями, так как индивидуальная когнитивная сфера самоубийцы предполагает критическое намерение лица совершить акт самоуничтожения, подавляя при этом инстинкт самосохранения. На 
практике эта форма суицидального терроризма выражается, как правило, в подрыве террористами самих себя через использование так называемых «поясов шахидов», а также использование начинённых взрывчаткой автотранспортных средств, управляемых террористами смертниками.

Суицидальный терроризм высокой вероятности означает, что террористический акт совершается исполнителями без непосредственного самоубийства, однако развитие дальнейших событий, связанных с силовым противодействием агрессии террористов, предполагает высокую вероятность уничтожения самих террористов. Для идентификации этой формы суицидального терроризма необходимо учитывать три момента. Во-первых, террористы должны быть уничтожены во временных границах проводимого террористического акта, во-вторых, террорист ещё на стадиях подготовки, покушения и осуществления террористической атаки должен осознавать высокую вероятность того, что его физически ликвидируют и, в-третьих, должны отсутствовать какие-либо обеспечительные меры прикрытия и отхода после совершения преступления. При суицидальном терроризме высокой вероятности самоубийства в традиционном понимании этого явления нет, так как террорист погибает от рук других лиц (самих потерпевших, сотрудников правоохранительных органов, военных и др.). В то же время суицидальный характер терроризма имеет место быть, так как террорист сознательно создаёт особые условия, которые закономерно должны привести к его гибели при том, что сам террорист это понимает и сознательно идёт на совершение террористического преступления.

Суицидальный терроризм следует отличать от квазисуицидального терроризма. Квазисуицидальный терроризм представляет собой обманное использование человека в террористических целях, которое приводит к уничтожению лица, находящегося в добросовестном заблуждении. Показательным примером такой формы терроризма является использование через обман или злоупотребление доверием людей для сокрытия взрывных устройств, которые в дальнейшем дистанционно приводятся в исполнение самим террористом. С социально-психологической стороны подобную террористическую практику сложно отнести к суицидальному терроризму, так как сам террорист остаётся жив. В действительности террорист использует другого человека в террористических целях без его согласия через манипулирование его сознанием, что характеризует погибшего человека не как террориста, а скорее как жертву теракта.

Анализ количественных показателей распространения суицидального терроризма в XXI веке позволяет выявить некоторые закономерности и тенденции. Прежде всего, следует отметить быстрые темпы географического распространения и количественного увеличения террористических атак смертников (suicide attack). Так, например, в соответствии с информационно-аналитической базой данных Чикагского проекта по безопасности и терроризму Chicago Project on Security and 
Terrorism database (CPOST) за период 1982-2016 гг. были совершены в общей сложности 5292 суицидальные террористические атаки, повлекшие 52966 смертей, при этом 132423 лица пострадали от ранений различной степени тяжести [26] (рис. 1). Если учитывать средний удельный коэффициент причинения вреда (смертность и ранения) от террористического акта, то он приблизительно равняется 35 потерпевшим (из них 10 погибших и 25 раненых) на один суицидальный акт терроризма.

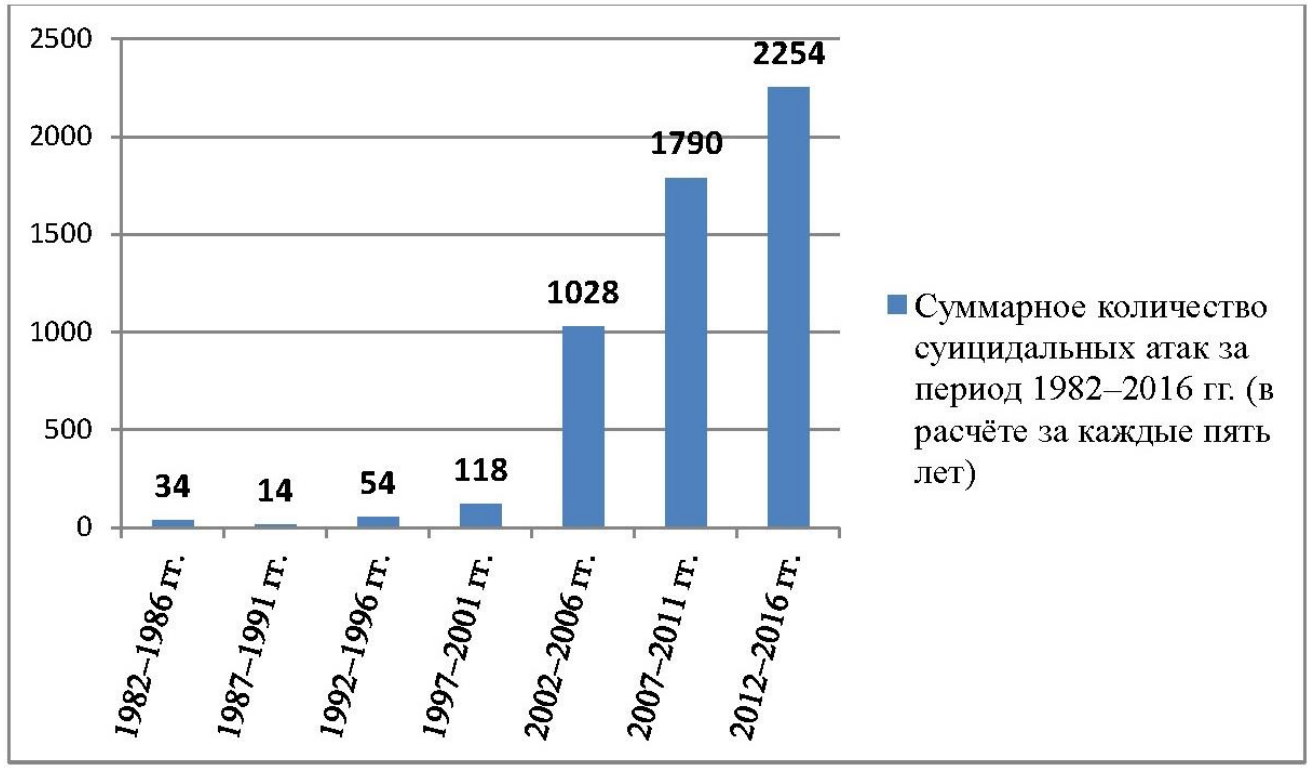

Рuc. 1. Динамика суицидальных атак за период 1982-2016 гг. (в расчёте за каждые пять лет). Источник: составлено авторами на основе [26]

Следует отметить, что суицидальные террористические атаки с 1982 г. по 2001 г. в практике террористической деятельности в целом занимали незначительное место. Общее количество суицидальных атак за этот период составило 220 актов, повлекших убийства 5927 человек и причинение вреда здоровью в отношении 18344 потерпевших. Однако в период 2002-2016 гг. наблюдается интенсификация совершения суицидальных террористических актов, приведшая к многократному увеличению количества жертв. За этот период было совершено 5072 суицидальных атак, повлекших 47039 смертей и 114079 потерпевших от ранений различной тяжести.

Происходит изменение и географии террористических атак. Так, если в период 1982-2001 гг. большинство террористических суицидальных атак были совершены в таких странах, как Шри-Ланка (71 атака), Ливан (42 атаки), Израиль (15 атак), Турция (12 атак), Палестина (11 атак), Россия (9 атак), Индия (4 атаки), то в период 
2001-2016 гг. большая часть суицидальных атак была совершена в Ираке (2 152 атаки), Афганистане (1 145 атак), Пакистане (515 атак), Сирии (259 атак), Нигерии (175 атак), Йемене (136 атак), Сомали (117 атак). При этом необходимо также отметить, что количество суицидальных атак растет и в странах первой группы. Например, в России за последние 16 лет было совершено 79 суицидальных террористических атак, в Израиле соответственно - 99, в Шри-Ланке - 44, в Турции - 31, в Индии - 11 атак.

Изменяется также и тактика суицидального терроризма, что объясняется переориентацией террористических организаций на новые способы совершения суицидальных атак общеопасным способом. Если в период 1982-2001 гг. суицидальные террористические атаки совершались через взрывы автомобилей, начинённых взрывчаткой (39,7\% от всех атак за отчётный период), и использование поясов смертников (39,7\% от всех атак за отчётный период) то в период 2002-2016 г. суицидальная террористическая тактика через подрывы автомобилей составила уже $56,4 \%$ от всех атак за отчётный период, а использование поясов шахида составило $36,5 \%$ от всех атак за отчётный период. При этом данный период характеризуется появлением нового способа проведения суицидальной террористической атаки, который выражается в использовании летательных аппаратов (прежде всего самолётов) против гражданских объектов (здания, строения, технические сооружения). Хотя подобная тактика суицидального терроризма является относительно новой (всего четыре инцидента), в то же время нельзя недооценивать разрушительные последствия от совершения таких атак. В недавней истории известны беспрецедентные террористические акты, совершённые с использованием пассажирских самолетов, произошедшие 11 сентября в США. В результате совершения четырёх таких атак было убито 2978 человек и более 6300 человек получили ранения различной тяжести.

В то же время, наблюдается некоторое снижение удельного коэффициента причинения вреда от суицидального терроризма, осуществляемого через использование автотранспортных средств. Так, коэффициент причинения вреда от суицидальных атак, совершаемых при помощи автомобилей, снизился с 21,2 (за период 1982-2001 гг.) до 8,9 (за период 2002-2016 гг.). При этом в сравнительном контексте за оба периода происходит многократное увеличение количества автомобильных суицидальных атак (с 83 атак за период с 1982-2001 гг. до 2781 акта за период 2002-2016 гг.). Представленные показатели иллюстрируют две закономерности: с одной стороны, автомобильные суицидальные атаки осуществляются всё чаще, что позволяет говорить о популярности этой террористической тактики, с другой стороны, снижение коэффициента причинения вреда от таких атак свидетельствует об уменьшении разрушительного эффекта относительно каждой атаки.

Наблюдается также корреляционное изменение совершения суицидальных атак с помощью поясов смертников (поясов шахидов). За период 1982-2001 гг. 
было совершено 81 подобных террористических актов, убивших 634 человека и причинивших физический вред здоровью 2538 лицам. Удельный коэффициент причинения вреда за данный период террористической суицидальной практики составил 7,6. Вместе с тем наблюдается существенное увеличение количества подобных суицидальных атак после 2001 г. За период 2002-2016 гг. было совершено 1797 террористических актов с использованием поясов шахидов, убивших 18775 человек и причинивших вред здоровью 43307 лицам. Темп роста таких атак по сравнению с предыдущим периодом составил $2218 \%$, что наглядно демонстрирует широкое распространение суицидальных террористических актов, совершаемых с использованием поясов смертников. Возросла и эффективность данной террористической практики, выраженная в росте удельного коэффициента причинения вреда с 7,6 за предыдущий период до 10,4 за последний исследуемый период (рис. 2).

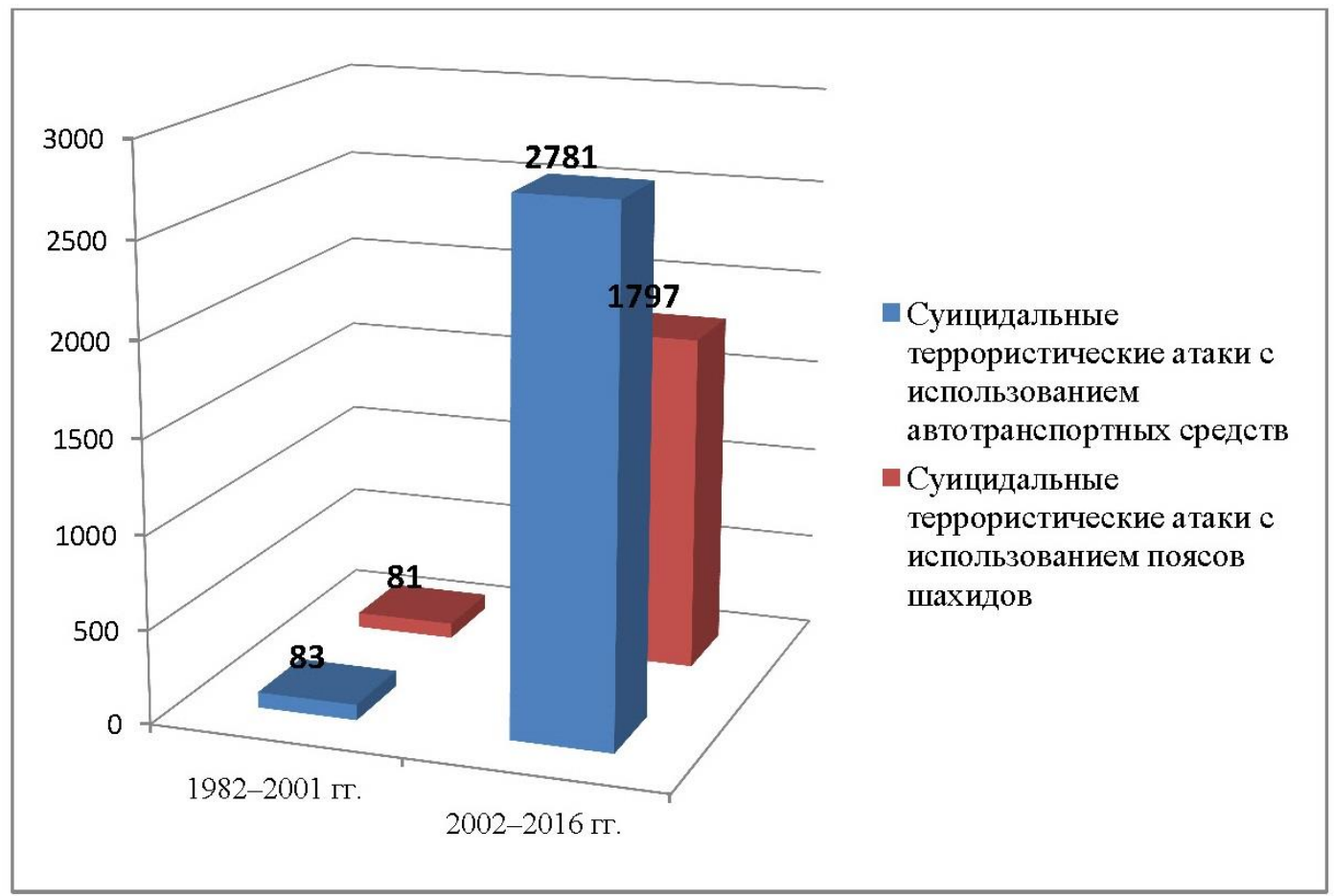

Puc. 2. Количественные показатели изменения тактики суицидального терроризма. Источник: составлено авторами на основе [26]

Отдельно следует сказать о гендерной дифференциации суицидального терроризма. Так, за период с 1985 г. по 2018 г. было совершено более 300 суицидальных атак с участием хотя бы одной из женщин, в результате чего погибло 
3071 человек, в то время суицидальные террористические акты, совершенные мужчинами-смертниками, унесли жизни 55216 человек. В общей сложности за указанный период удельный вес террористических актов, совершённых женщинами-самоубийцами, не превышает $2 \%$, а смертность от их совершения составляет $5,3 \%$. При этом большая часть суицидальных террористических актов с участием женщин приходится на такие террористические структуры, как Боко Харам (48\%), чеченские террористические группы (16\%) и Тигры освобождения Тамил-Илама (6\%). Если же рассматривать распространение женского суицидального терроризма за указанный период в привязке к географическому критерию, то более 30\% от общего числа смертниц приходится на Камерун, Нигерию и Россию [27].

Вместе с тем, далеко не все существующие в XXI в. террористические организации прибегают к суицидальной террористической практике. Так, если проводить сравнительно-статистический анализ всех террористических актов за 2014 г. (всего было совершено 32685 актов) по отношению к суицидальным актам терроризма за этот же период, то доля суицидального терроризма не превышает 1,8\% от общего количества террористических атак (в 2014 г. было совершено 598 суицидальных атак) [28].

Однако следует понимать, что суицидальная практика терроризма дифференцирована в своём проявлении. Методом сплошного анализа была изучена террористическая деятельность 117 наиболее опасных террористических организаций, образующих в своей взаимосвязи международный террористический интернационал [29]. Из всех рассматриваемых террористических организаций только 11 на постоянной и систематической основе прибегают к суицидальной практике политического насилия. Среди таких организаций можно отметить: Талибан (717 суицидальных атак), Исламское государство (585 суицидальных атак), Аль-Каида (188 суицидальных атак), Техрик-е Талибан (147 суицидальных атак), Аль-Шабаб (82 атаки), Джебхат ан-Нусра (62 суицидальных атаки), Хамас (60 атак), Движение исламского джихада в Палестине (43 суицидальные атаки), Бригады мучеников аль-Аксы (40 атак), Тигры освобождения Тамил-Илама (32 атаки) и Боко Харам (23 атаки) [26] (рис. 3).

Суицидальная террористическая деятельность востребована террористическими организациями по ряду причин. Прежде всего, подготовка террориста-смертника обходится сравнительно недорого. В специальной литературе отмечается, что на подготовку одного террориста-смертника тратится от 150 до 2000 долларов. В некоторых случаях террористические организации выплачивают компенсационные средства в размере от 3000 до 5000 долларов семьям террористов-смертников. Дополнительные траты также необходимы для приобретения средств связи, взрывчатки и амуниции [6; 7]. Суицидальный терроризм при низких финансовых затратах на подготовку террористов-смертников, как правило, приводит к разруши- 
тельным последствиям в экономической (например, изменение курса национальной волюты, прекращение зарубежных инвестиций, закрытие предприятий, «бегство капитала», снижение туризма и многое другое), политической (подрыв авторитета государственной власти, дискредитация политических деятелей, недоверие к власти и т.д.) и социальной (появляются беженцы и вынужденные переселенцы, возникает напряжённость в обществе и общественное осуждение властных институтов, неспособных обеспечить безопасность граждан) сферах.

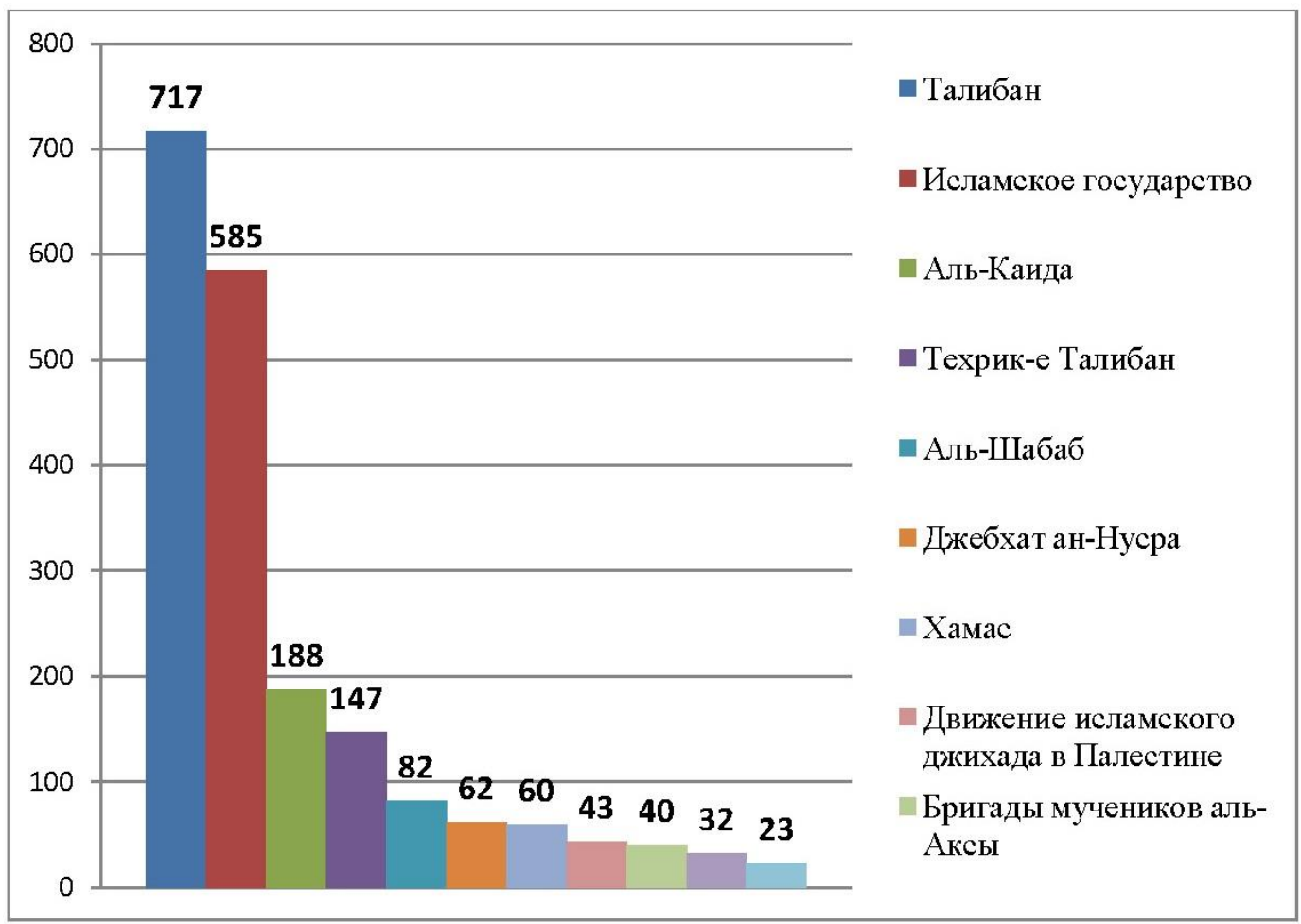

Рис. 3. Основные террористические организации, которые на постоянной основе прибегают к суицидальной практике политического насилия (за период 2000-2016 гг.).

Источник: составлено авторами на основе [26]

В исторической ретроспективе практика суицидального терроризма хотя и не является абсолютно эффективным средством влияния на политику зарубежных государств, в то же время оказывает значительное воздействие на военное присутствие иностранных военных контингентов. Это воздействие выражается в том, что понимание террористических угроз (в том числе суицидального терроризма как наиболее опасного проявления этих угроз) приводит к принятию дополнительных мер безопасности дислоцированных за границей вооруженных сил, а как следствие - и к дополнительному финансированию зарубежных кампаний. Кроме 
того, как это ни парадоксально будет звучать, но суицидальный терроризм в определённых условиях может выступать как пропагандистское мероприятие в том плане, что средства массовой информации зачастую благосклонно пытаются объяснить суровые жизненные условия, вынудившие пойти человека на преступление, a террористические организации специально разогревают общественный интерес к суицидальным акциям, буквально обожествляя их исполнителей, что опять же приводит к увеличению желающих покончить с собой во имя благих целей, при этом лишив жизни какое-то количество человек [8, с. 223].

Особое внимание следует обратить на социально-психологические причины, порождающие суицидальный терроризм в широком проявлении. В принципе можно говорить о двух ключевых подходах относительно понимания детерминации суицидального терроризма. В контексте первого подхода суицидальный терроризм объясняется с позиции религиозного самосознания и кризиса культурно-национальных ценностей, исторически складывающихся в традиционном обществе. В сущности, речь идет о возникновении антагонистических отношений в межкультурном коммуникационном взаимодействии (пространстве), где происходит столкновение традиционных ценностей исламского мира с аксиологическим миропониманием, отражённым в «западной цивилизации». При этом вмешательство «западной цивилизации» в традиционные общества порождает кризис культурной идентичности, под чем понимается изменение ценностных ориентаций и их иерархии, смена критериев оценки удовлетворённости жизнью и представлений о собственном благополучии, безудержная тяга к новому, усиление экстремистских устремлений, отсутствие устойчивых «идеалов и идолов», а также размытость будущих перспектив [9, с. 174]. С психологической стороны мотивационный комплекс террористов-смертников охватывает определённые страхи, желания, фобии и увлечения, которые возникают в связи с определённым пониманием религиозных, философских, эзотерических ценностных установлений и которые в своей взаимообусловленности являются достаточными для совершения решительных действий террористического характера. Религиозный фактор социально-психологической детерминации суицидального терроризма выражается в превалировании духовных квазиценностей в сознании человека, которые формируются через последовательное программирование потенциального субъекта предстоящей суицидальной террористической деятельности в целях подавления в нём инстинкта самосохранения и развития стремления к «духовному очищению» через героическое самоубийство. Ключевой особенностью религиозного суицидального терроризма выступает потребность и стремление к тому, чтобы через совершение криминальных действий попасть в рай. Сама террористическая деятельность и ужасающие последствия воспринимаются как своеобразные ритуальные условия, необходимые для попадания в рай. В этом плане интересно отметить, что трансцендентальное понимание лучшей жизни (в религиозном контексте речь идёт о попада- 
нии души в рай) обесценивает ценность собственной человеческой жизни и порождает пренебрежительное отношение к другим людям, которые воспринимаются исключительно либо как «неверные», либо как объекты жертвоприношения. Однако было бы неправильно во всех случаях объяснять агрессивный суицид религиозными верованиями, так как разные религии и сакраментальные учения по-разному определяют смысл человеческой жизни и допустимость её лишения. Например, в исламе и христианстве суицид категорически отрицается и воспринимается как греховное деяние, однако индуизм и синтоизм, напротив, разрешают при определённых условиях религиозные самоубийства [10, с. 37-40]. Но сама по себе религия, взятая в модельном выражении и безотносительно к уровню социального одобрения и восприятия, не является фактором, детерминирующим развитие суицидального терроризма. В этой связи уместно рассматривать не столько саму религию (религиозное учение), сколько уровень религиозности населения в той или иной стране. Отечественные и зарубежные исследования взаимосвязи религиозности населения с суицидальными актами, проведённые в разных странах, в целом не подтверждают презумпцию о том, что в обществах с высоким уровнем религиозного сознания в большей мере совершаются суициды, включая суицидальные террористические акты, нежели в странах, где преобладающей становится светская мораль [11; 12]. Религиозный фактор в предупреждении суицидального поведения объясняется не самой религией и состоянием набожности, а скорее приобщением человека к определённой религиозной общности, культивирующей и воспринимающей религиозные догмы и ценности как императивные требования. Такой подход согласуется с теорией Э. Дюркгейма, в соответствии с которой благотворительное влияние религии не сводится к специальной природе религиозных идей, сохраняющих человека от самоуничтожения, а в том, что религия, в сущности, проецирует особые социальные отношения, основанные на общих верованиях и обычаях, признаваемых всеми верующими, освящённых традицией и потому обязательных [13, с. 78]. Вместе с тем в аспекте сказанного следует оговориться о том, что не все религиозные (в широком смысле слова) учения, поддерживаемые определёнными социальными группами и отражаемые в специфическом массовом сознании, априори обеспечивают ориентацию на сохранение человеческой жизни как особой трансцендентальной ценности. Напротив, как доказывают исследования суицидального терроризма, в религиозных сообществах также могут формироваться устремления к суицидальным действиям, поддерживаемым и одобряемым представителями таких объединений [14, p. 658]. В этом плане достаточно отметить неоднократные случаи суицидов, совершённых в тоталитарных сектах, а равно суицидальные террористические атаки, осуществлённые представителями религиозноэкстремистских организаций.

Одновременно следует признать, что связь религии и суицидальной практики терроризма не всегда прослеживается в статистической отчётности и подтверждается 
в научной сфере. Например, в зарубежной научно-аналитической литературе отмечают, что за период 1981-2010 гг. общее количество суицидальных террористических атак в 35 странах мира составило 2233 инцидент, при том что только более 800 террористических суицидальных атак (около 36 \%) были совершены по религиозным мотивам [15, p. 13-21]. В научной литературе также отмечается, что суицидальные террористические акты часто совершаются в целях предупреждения возможного выхода из террористических сект и наказания провинившихся членов этих деструктивных сообществ [16, p. 990-995], либо же суицидальный терроризм выступает проявлением практицизма, ориентированного на достижение цели любыми средствами с учётом некоторой диффузии обучения со сходными религиозными традициями [17, p. 38-45]. Кроме того, нельзя игнорировать и другие факторы, которые в системной совокупности обусловливают повышенную вероятность суицидального терроризма. В частности, к таким факторам можно отнести злоупотребление наркотиками, воспитание в неблагополучных семьях, физические или психические нарушения, субъективные моральные недостатки, депрессии, страхи. Суицидальная террористическая практика также может детерминироваться спецификой внутригрупповых отношений, которые характеризуются высоким уровнем сплоченности и обилием крайних радикальных убеждений, воспроизводство, обоснование и распространение которых приводит к усилению агрессивности (включая агрессивный суицид) [18, p. 178].

Таким образом, актуализируется второй подход в объяснении суицидального терроризма, при котором возникает социальный протест против несправедливой системы социальной организации и сложившихся общественных отношений. В рамках этого подхода общеопасный акт самоубийства совершается в целях воздействия на публичные органы власти с тем, чтобы изменить социальную стратификацию, ликвидировать дискриминационные отношения, редуцировать риски социальной несправедливости, а также изменить сложившуюся систему распределения общественных благ.

Вместе с тем оба подхода, объясняющие суицидальный терроризм (и религиозный, и социальный), имеют общие характеристики. Во-первых, суицидальная террористическая практика становится возможной только при условии, если существует особый контингент лиц, готовых совершить акты самоубийств в террористических целях. В свою очередь, подготовка такого контингента предполагает разработку и применение специальных психологических методик, направленных на развитие особой мотивации на совершение террористических преступлений. Сама процедура подготовки террористовсмертников включает в себя ряд последовательных действий, направленных на поиск и вербовку кандидатов в террористы и психологическую обработку этих лиц в целях склонения их к совершению террористического акта через 
самопожертвование. При этом основной упор при отборе и вербовке террористическое подполье делает на особый контингент лиц, а именно: лица, имеющие психологические травмы и (или) находящиеся в так называемом пограничном состоянии психики и постоянно ищущие смерти; родственники ранее уничтоженных боевиков, стремящиеся отомстить; женщины с неустроенной судьбой или трагедией в личной жизни; идейные и религиозные фанатики; дети и лица, не имеющие близких родственников [19, с. 59-61]. Здесь важно понимать, что на роль террориста-смертника в наибольшей мере подходят лишь те лица, которые в социально-психологическом отношении с большей долей вероятности могут быть склонены к террористическим действиям при условии адекватной идеологической и психологической подготовки. Другими словами, эффективность применения специальных методик по обработке будущих террористов-смертников ставится в зависимость от степени уязвимости психики человека.

Во-вторых, наблюдается некоторая схожесть социально-психологических характеристик террористов-смертников, что выражается в относительно высоком уровне образования, материальном благополучии и молодом возрасте террористов. В специальной литературе по этому поводу отмечается, что образованные молодые люди имеют сильные альтруистические чувства, что предопределяет более решительное участие в террористической деятельности для обеспечения общественного блага в отношении будущих поколений [20-22]. Кроме того, отмечается также, что получение образования при определенных условиях может оказывать два негативных эффекта, предопределяющих возможное участие в террористической деятельности: 1) получение образования не всегда предполагает доступ к более высокооплачиваемым сегментам рынка труда; 2) получение образования может детерминировать при определённых обстоятельствах изменения уровня лояльности в связи с изменением мировоззренческой системы ценностей [23, р. 359]. В других исследованиях детерминации суицидального терроризма отмечается, что не альтруистическая мотивация для образованных молодых людей является лейтмотивом такой преступной деятельности, а социальное давление, заставляющее пойти на конформизм в сложившейся системе социальных отношений. Социальное давление особенно сильно сказывается на студентах, которые живут вдали от своих семей и которые вынуждены создавать замкнутый круг общения с другими студентами, в результате чего происходит генерирование и культивирование деструктивных идей, направленных на воспрепятствование чуждой культурной идентичности [24; 25].

В заключение следует отметить, что суицидальный терроризм с выраженной прогрессией становится наиболее опасной формой политического насилия, инспирируемого и осуществляемого террористическими организациями в условиях кризиса национально-культурной идентичности, геополитических противостояний, 
экономических потрясений и антагонистических международных процессов. Деструктивный прагматизм суицидального терроризма заключается в минимизации затрат на подготовку террористических атак при росте негативных последствий от непосредственного совершения самих актов терроризма, проявляемых в периоды политических, экономических и социальных потрясений. Учитывая эффективность современного суицидального терроризма, закономерно можно предположить, что в ближайшее время и в долгосрочной перспективе данная практика политического насилия будет возрастать по мере увеличения террористической активности в целом. Что касается социально-психологических аспектов суицидального терроризма, то здесь важно понимать, что терроризм смертников не сводится исключительно к религиозным причинам, а социальные корни этого явления не всегда происходят от низкого уровня образования и бедности. Вместе с тем, в тех случаях, когда религиозный фактор всё-таки детерминирует суицидальный терроризм, то он, вероятно, выражается в сплочении лиц в коллективное образование (так называемые террористические клики или микрогруппы деструктивного характера), культивирующее и поддерживающее квазиценности и идеалы.

\section{Список литературы}

1. The history of terrorism: from antiquity to al Qaeda / ed. by G. Chaliand, A. Blin; transl. by E. Schneider, K. Pulver, J. Browner. - [S. 1.] : University of California Press. $474 \mathrm{p}$.

2. Иванов, С. Н. Терроризм смертников: исторический аспект // Вестник Удмуртского университета. - 2008. - № 1. - С. 126-134.

3. Соснин, В. А. Современный терроризм: социально-психологический анализ / В. А. Соснин, Т. А. Нестик. - Москва : Ин-т психологии РАН, 2008. - 240 с.

4. Ольшанский, Д. В. Психология террора / Д. В. Ольшанский. - Москва : Академический Проект, 2014. - 320 с.

5. Schweitzer, Y. Suicide bombings - the ultimate weapon? - URL: https://www.ict.org.il/Article.aspx?ID=809 (дата обращения: 24.03.2021).

6. Оторбаев, У. Террористы-смертники - кто они? - URL: http:/www.eastti me.ru/analitic/3/3/992.html (дата обращения: 24.03.2021).

7. Капитонов, К. А. Война без правил. Израильско-палестинское противостояние / К. А. Капитонов. - Москва : АСТ; Восток - Запад, 2006. - 526 с.

8. Тараканов, А. В. Суицидальные атаки как средство политической борьбы // Вестник Бурятского государственного университета. - 2010. - № 6. - С. 219-223. C. 223 .

9. Шульгина, Д. Н. Кризис культуры и идентичности человека в условиях глобализации // Вестник ВГУ. Сер.: Философия. - 2010. - № 2. - С. 173-180. 
10. Суицидальное поведение и религиозность / В.Э. Пашковский, В. К. Шамрей, А. Г. Софронов, К. В. Днов, Н. Н. Ротковская // Суицидология. 2015. - T. 6, № 3 (20). - C. 30-41.

11. Lawrence, R. E. Religion and suicide risk: a systematic review / R. E. Lawrence, M. A. Oquendo, B. Stanley // Archives of suicide research. - 2016. - № 20. - P. 1-20.

12. O'Reilly, D. Religion and the risk of suicide: longitudinal study of over 1 million people / D. O'Reilly, M. Rosato // British Journal of Psychiatry. - 2015. - Vol. 206, № 6. - P. 466-570.

13. Дюркгейм, Э. Самоубийство: Социологический этюд / пер. с фр. с сокр. ; под ред. В. А. Базарова. - Москва : Мысль, 1994. - 399 с.

14. Matthew, D. M. Religious heterogeneity and suicide: A cross-national analysis // Social Compass. - 2015. - Vol. 62, № 4. - P. 649-663.

15. Filote, A. H. Suicide attacks and religious cleavages / A. Filote, N. Potrafke, H. Ursprung // Public Choice. - 2016. - Vol. 166. - P. 3-28.

16. Santifort-Jordan, C. An empirical study of suicide terrorism: a global analysis / C. Santifort-Jordan, T. Sandler // Southern Economic Journal. - 2014. - № 80. - P. 981-1001.

17. Horowitz, M. Non-state actors and the diffusion of innovations: The case of suicide terrorism // International Organization. - 2010. - Vol. 64. - P. 33-64.

18. Wintrobe, R. Extremism, suicide terror, and authoritarianism // Public Choice. 2006. - Vol. 128. - P. 169-195.

19. Бутков, П. П. Терроризм и проблемы безопасности в современном мире П. П. Бутков, А. И. Зайцев. - Санкт-Петербург : Изд-во Политехн. ун-та, 2015. - 336 с.

20. Azam, J. P. Suicide-bombing as inter-generational investment // Public Choice. 2005. - № 122 (1-2). - P. 177-198.

21. Azam, J. P. The roles of foreign aid and education in the war on terror / J. P. Azam, V. Thelen // Public Choice. - 2008. - № 135 (3-4). - P. 375-397.

22. Azam, J. P. Foreign aid vs. military intervention in the war on terror/ J. P. Azam, V. Thelen // Journal of Conflict Resolution. - 2010. - № 54 (2). - P. 237-261.

23. Azam, J. P. Why suicide-terrorists get educated, and what to do about it// Public Choice. - 2012. - № 153. - P. 357-373.

24. Ferrero, M. Martyrdom contracts // Journal of Conflict Resolution. - 2006. № 50 (6). - P. 855-877.

25. Wintrobe, R. Extremism, suicide terror, and authoritarianism // Public Choice. 2006. - № 128. - P. 168-195.

26. Suicide Attack Database. The Chicago Project on Security and Terrorism (CPOST). - URL: https://dss.princeton.edu/catalog/resource1057 (дата обращения: 24.03.2021).

27. Global Terrorism Index. Report. 2019 / The Institute for Economics and Peace. URL: https://reliefweb.int/sites/reliefweb.int/files/resources/GTI-2019web.pdf (дата обращения: 24.03.2021). 
28. Global Terrorism Index. Report. 2015 / The Institute for Economics and Peace. URL: http://economicsandpeace.org/wp-content/uploads/2015/11/2015-Global-Terrorism-Ind ex-Report.pdf (дата обращения: 24.03.2021).

29. Browse By Perpetrator Group / The Global Terrorism Database. - URL: https://www.start.umd.edu/gtd/search/BrowseBy.aspx?category=perpetrator (дата обращения: 24.03.2021).

\section{References}

1. The history of terrorism: from antiquity to al Qaeda / edited by Gérard Chaliand and Arnaud Blin; translated by E. Schneider, K. Pulver and J. Browner. [S. 1.]: University of California Press. 474 p.

2. Ivanov S. N. Terrorizm smertnikov: istoricheskii aspect [Suicide terrorism: historical aspect]. Vestnik Udmurskogo universiteta, 2008, no. 1, pp. 126-134.

3. Sosnin V. A., Nestik T. A. Sovremennyi terrorizm: sotsial'no-psikhologicheskii analiz [Modern terrorism. Socio-psychological analysis]. Moscow: Institute of psychology RAS Publ., 2008. 240 p.

4. Olshanskiy D. V. Psikhologiya terrora [The psychology of terror]. Moscow: Akademicheskii Proekt Publ., 2014. 320 p.

5. Schweitzer Y. Suicide bombings - the ultimate weapon? Available at: https://www.ict.org.il/Article.aspx?ID=809 (accessed 24 March 2021).

6. Otorbaev U. Suicide bombers - who are they? Available at: http://www.easttime.ru/analitic/3/3/992.html (accessed 24 March 2021).

7. Kapitonov K. A. Voina bez pravil. Izrail'sko-palestinskoe protivostoyanie [War without rules. The Israeli-Palestinian conflict]. Moscow: AST. Vostok-Zapad Publ., 2006. 526 p.

8. Tarakanov A. V. Suitsidal'nye ataki kak sredstvo politicheskoi bor'by [Suicide attacks as a means of political struggle]. Vestnik Buryatskogo gosudarstvennogo universiteta, 2010, no. 6, pp. 219-223.

9. Shulgin D. N. Krizis kul'tury i identichnosti cheloveka v usloviyakh globalizatsii [The crisis of culture and identity in the context of globalization]. Vestnik VGU. Ser.: Filosofiya, 2010, no. 2, pp. 173-180.

10. Pashkovskiy V. E., Shamrei V. K., Sofronov A. G., Dnov K. V., Rotkovskaya N. N. Suitsidal'noe povedenie i religioznost' [Suicidal behaviour and religiosity]. Suitsidologiya, 2015, vol. 6, no. 3 (20), pp. 30-41.

11. Lawrence R. E., Oquendo M. A, Stanley B. Religion and suicide risk: a systematic review. Archives of suicide research, 2016, no. 20, pp. 1-20.

12. O'Reilly D., Rosato M. Religion and the risk of suicide: longitudinal study of over 1 million people. British Journal of Psychiatry, 2015, vol. 206, no. 6, pp. 466-570.

13. Durkgeym A. Samoubiistvo: Sotsiologicheskii etyud [Suicide: a study in sociology]. Moscow: Mysl' Publ., 1994. 399 p. 
14. Matthew D. M. Religious heterogeneity and suicide: A cross-national analysis. Social Compass, 2015, vol. 62, no. 4, pp. 649-663.

15. Filote A., Potrafke N., Ursprung H. Suicide attacks and religious cleavages. Public Choice, 2016, vol. 166, pp. 3-28.

16. Santifort-Jordan C., Sandler T. An empirical study of suicide terrorism: a global analysis. Southern Economic Journal, 2014, no. 80, pp. 981-1001.

17. Horowitz M. Non-state actors and the diffusion of innovations: The case of suicide terrorism. International Organization, 2010, vol. 64, pp. 33-64.

18. Wintrobe R. Extremism, suicide terror, and authoritarianism. Public Choice, 2006, vol. 128, pp. 169-195.

19. Butkov P. P., Zaitsev A. I. Terrorizm i problemy bezopasnosti v sovremennom mire [Terrorism and security issues in the modern world]. St.-Petersburg: Polytekhnic University Publ., 2015. 336 p.

20. Azam J. P. Suicide-bombing as inter-generational investment. Public Choice, 2005, no. 122 (1-2), pp. 177-198.

21. Azam J. P., Thelen V. The roles of foreign aid and education in the war on terror. Public Choice, 2008, no. 135 (3-4), pp. 375-397.

22. Azam J. P., Thelen V. Foreign aid vs. military intervention in the war on terror. Journal of Conflict Resolution, 2010, no. 54 (2). pp. 237-261.

23. Azam J. P. Why suicide-terrorists get educated, and what to do about it. Public Choice, 2012, no. 153, pp. 357-373.

24. Ferrero M. Martyrdom contracts. Journal of Conflict Resolution, 2006, № 50 (6), pp. 855-877.

25. Wintrobe R. Extremism, suicide terror, and authoritarianism. Public Choice, 2006, no. 128, pp. 168-195.

26. Suicide Attack Database. The Chicago Project on Security and Terrorism (CPOST). Available at: https://dss.princeton.edu/catalog/resource1057 (accessed 24 March 2021).

27. Global Terrorism Index. Report. 2019. The Institute for Economics and Peace. Available at: https://reliefweb.int/sites/reliefweb.int/files/resources/GTI-2019web.pdf (accessed 24 March 2021).

28. Global Terrorism Index. Report. 2015. The Institute for Economics and Peace. Available at: http://economicsandpeace.org/wp-content/uploads/2015/11/2015-GlobalTerrorism-Index-Report.pdf (accessed 24 March 2021).

29. Browse By Perpetrator Group. The Global Terrorism Database. Available at: https://www.start.umd.edu/gtd/search/BrowseBy.aspx?category=perpetrator (accessed 24 March 2021). 